Supporting Information:

\title{
A Cholic Acid-based Fluorescent Sensor for Dicarboxylates and Acidic Amino Acids in Aqueous Solutions
}

\author{
Shun-Ying Liu, ${ }^{\dagger \neq}$ Lei Fang, ${ }^{\dagger \ddagger}$ Yong-Bing He, ${ }^{\dagger}$ \\ Wing-Hong Chan, ${ }^{\star \ddagger}$ Kai-Tai Yeung, ${ }^{\ddagger}$ Yuen-kit \\ Cheng, ${ }^{\ddagger}$ Rong-Hua Yang \\ ${ }^{\dagger}$ Department of Chemistry, Wuhan University, Hubei, China, \\ Department of Chemistry and Central Laboratory of the Institute \\ of Molecular Technology for Drug Discovery and Synthesis, \\ Hong Kong Baptist University, Hong Kong SAR, China and \\ Department of Chemical Biology, College of Chemistry and \\ Molecular Engineering, Peking University
}

whchan@hkbu.edu.hk

Table of contents:

1. General experimental section 


\section{Experimental Section}

\section{General}

Melting point was determined with a MEL-TEMP $\sqsupset$ melting-piont apparatus (uncorrected). IR spectra were obtained on a Nicolet MAGNA-IR550 spectrophotometer. ${ }^{1} \mathrm{H}$ NMR spectra were recorded in DMSO- $\mathrm{d}_{6}$, with $\mathrm{Me}_{4} \mathrm{Si}$ as internal standard, on a JEOL EX270 spectrometer and ${ }^{13} \mathrm{C}$ NMR spectra on a Varian INOVA-400 FT NMR spectrometer. High-resolution mass spectra (MALDI-TOF-HRMS) were recorded on a Autoflex mass spectrometer. Absorption spectra were detected on a Hewlett Packard 8453 UV-Visible spectrophotometer. Fluorescent emission spectra were collected on a spectrofluorimeter from Photon Technology International (PTI), consisting of a lamp power supply (model LPS-220), a xenon lamp (model LPS-A1010). $\mathrm{CH}_{2} \mathrm{Cl}_{2}$ was dried and distilled from $\mathrm{CaH}_{2}$. Diethylene glycol dimethyl ether was distilled from $\mathrm{CaCl}_{2}$ and $\mathrm{DMF}$ from $\mathrm{MgSO}_{4}$ under reduced pressure. THF was distilled under nitrogen in the presence of sodium chips using benzophenone ketyl as the indicator. All other commercially available reagents were used without further purification. The compound 2 was synthesized according to the literatures. ${ }^{13 \mathrm{~b}}$

\section{Synthesis}

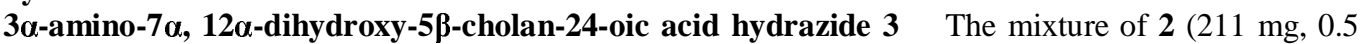
$\mathrm{mmol})$ and hydrazine $(0.5 \mathrm{~mL}$, large excess $)$ monohydrate in methanol $(10 \mathrm{~mL})$ was stirred under nitrogen at ambient temperature for $24 \mathrm{~h}$. Then methanol and most of the hydrazine were removed under reduced pressure. The residue.was poured into $30 \mathrm{~mL}$ of cooled water and stirred for $10 \mathrm{~min}$. After filtration, the solid was washed with $3 \times 20 \mathrm{~mL}$ of cooled water and dried in vacuum at $60 \sqsupset$. The product was obtained as a white solid in $96 \%$ yield $(202 \mathrm{mg})$ and needed no further purification for the next reaction: m.p.: decomposed at 166 $\sqsupset .{ }^{1} \mathrm{H}$ NMR $\left(270 \mathrm{MHz}, \mathrm{DMSO}-d_{6}\right): \delta 0.57(\mathrm{~s}, 3 \mathrm{H}), 0.81(\mathrm{~s}, 3 \mathrm{H})$, $0.91(\mathrm{~d}, 3 \mathrm{H}, J=6.4 \mathrm{~Hz}), 2.38(\mathrm{~m}, 1 \mathrm{H}), 3.60(\mathrm{~s}, 1 \mathrm{H}), 3.77(\mathrm{~s}, 1 \mathrm{H}), 4.08-4.13(\mathrm{~m}, 3 \mathrm{H})$. MALDI TOF HRMS: calcd for $\mathrm{C}_{24} \mathrm{H}_{43} \mathrm{~N}_{3} \mathrm{O}_{3}+\mathrm{H}, 422.3382$; found, 422.3394 .

$N$-[(9'- methlyeneanthracene) thioureido] $3 \alpha-\left[\left(9^{\prime}\right.\right.$ '- methlyeneanthracene) thioureido $]-7 \alpha, 12 \alpha-$ dihydroxy-5 $\beta$-cholan-24-oxamide $1 a$ To a solution of $3(126 \mathrm{mg}, 0.3 \mathrm{mmol})$ in dried DMF $(5 \mathrm{~mL})$, 9-isothiocyanomethylanthrance $(174 \mathrm{mg}, 0.7 \mathrm{mmol})$ was added and heated at $50 \sqsupset$ for $24 \mathrm{~h}$ under nitrogen. Most of the DMF was removed under reduced pressure and the residue was taken up by $\mathrm{CH}_{2} \mathrm{Cl}_{2}$. The organic solution was first washed by saturated brine and the dried by sodium sulfate. Column chromatography $\left(\mathrm{SiO}_{2}\right)$ eluted by the solvent of ethanol/dichloromethane $(1: 20)$ gave the pure product 1a as a yellow solid (102 mg, 37\%): m.p. 198-200 $\sqsupset .{ }^{1} \mathrm{H}$ NMR (270MHz, DMSO- $\left.d_{6}\right): \delta 0.51(\mathrm{~s}$, $3 \mathrm{H}), 3.87(\mathrm{~m}, 1 \mathrm{H}), 4.04(\mathrm{~s}, 1 \mathrm{H}), 4.11(\mathrm{~s}, 1 \mathrm{H})$, 5.57, $5.67(2 \mathrm{~s}$, total $4 \mathrm{H}), 7.20(\mathrm{~s}, 1 \mathrm{H}), 7.46(\mathrm{~s}, 1 \mathrm{H})$, 7.59 (m, $8 \mathrm{H}), 7.93$ (br, $1 \mathrm{H}), 8.16(\mathrm{~m}, 4 \mathrm{H}), 8.42$ (m, $4 \mathrm{H}), 8.66(\mathrm{~s}, 1 \mathrm{H}), 8.68(\mathrm{~s}, 1 \mathrm{H}), 9.51$ (br, $2 \mathrm{H})$. ${ }^{13} \mathrm{C}$ NMR $\left(100 \mathrm{MHz}, \mathrm{DMSO}-d_{6}\right): 12.3,17.1,22.8,25.9,26.2,27.3,28.6,30.4,31.2,34.4,34.8,35.1$, $35.8,40.1,41.0,41.4,45.7,46.1,53.8,66.3,71.0,124.5,124.7,125.4,125.5,125.8,126.1,126.5$, $126.7,126.9,127.6,127.8,129.0,129.1,129.5,129.7,130.1,131.2,133.1,134.7,172 . .9,181.5,182.6$. IR (KBr): 3422, 2930, 2865, 1654, 1646, 1637, 1624, 1534, 1471, 1447, 1376, 1332, 1311, $733 \mathrm{~cm}^{-1}$. MALDI TOF HRMS: calcd for $\mathrm{C}_{56} \mathrm{H}_{65} \mathrm{~N}_{5} \mathrm{O}_{3} \mathrm{~S}_{2}+\mathrm{H}, 920.4607$; found, 920.4645 .

Methyl 3 $\alpha$-[(9'- methlyeneanthracene) thioureido ]-7 $\alpha, 12 \alpha$-dihydroxy-5 $\beta$-cholan-24-oate $1 b$ To a solution of $2(106 \mathrm{mg}, 0.25 \mathrm{mmol})$ in dried DCM $(5 \mathrm{~mL})$, 9-isothiocyanomethylanthrance $(87 \mathrm{mg}, 0.35$ mmol) was added and heated at $50 \sqsupset$ for $16 \mathrm{~h}$ under nitrogen. Most of the $\mathrm{CH}_{2} \mathrm{Cl}_{2}$ was removed under reduced pressure. Column chromatography $\left(\mathrm{SiO}_{2}\right)$ eluted by the solvent of ethanol/dichloromethane (1:20) gave the pure product $\mathbf{1 b}$ as a yellow solid $(90 \mathrm{mg}, 54 \%)$ : m.p. decomposed at $160 \sqsupset .{ }^{1} \mathrm{H}$ NMR $\left(270 \mathrm{MHz}, \mathrm{CDCl}_{3}\right): \delta 3.65-3.91(\mathrm{~m}, 6 \mathrm{H}), 5.61(\mathrm{~s}, 2 \mathrm{H}), 6.15(\mathrm{br}, 1 \mathrm{H}), 7.47-7.55(\mathrm{~m}, 4 \mathrm{H}), 8.02(\mathrm{~d}, 2 \mathrm{H}, J$ $=8.4 \mathrm{~Hz}), 8.28(\mathrm{~d}, 2 \mathrm{H}, J=8.9 \mathrm{~Hz}), 8.45(\mathrm{~s}, 1 \mathrm{H}) .{ }^{13} \mathrm{C} \mathrm{NMR}\left(100 \mathrm{MHz}, \mathrm{CDCl}_{3}\right): 12.2,12.5,14.1,17.2$, $17.3,21.5,22.3,22.5,22.6,23.1,26.2,26.5,26.7,27.3,27.4,27.5,28.2,30.7,30.8,30.9,31.0,34.2$, $34.4,34.6,34.8,35.0,35.1,35.3,36.0,39.0,39.5,41.0,41.4,41.6,42.0,46.1,46.4,46.7,47.1,51.5$, $54.1,68.2,68.4,72.9,73,74.2,124.2,125.2,126.6,127.2,129.0,130.5,131.4,134.2,174.9,181.6$. IR (KBr): 3433, 2938, 2881, 1716, 1700, 1652, 1646, 1558, 1540, 1461, 1451, 1384, 1249, $736 \mathrm{~cm}^{-1}$. MALDI TOF HRMS: calcd for $\mathrm{C}_{41} \mathrm{H}_{54} \mathrm{~N}_{2} \mathrm{O}_{4} \mathrm{~S}_{1}+\mathrm{H}, 671.3882$; found, 671.3850 .

2. ${ }^{1} \mathrm{H}$ NMR and ${ }^{13} \mathrm{C}$ NMR spectra of $\mathbf{1 a}$ and $\mathbf{1 b}$ 


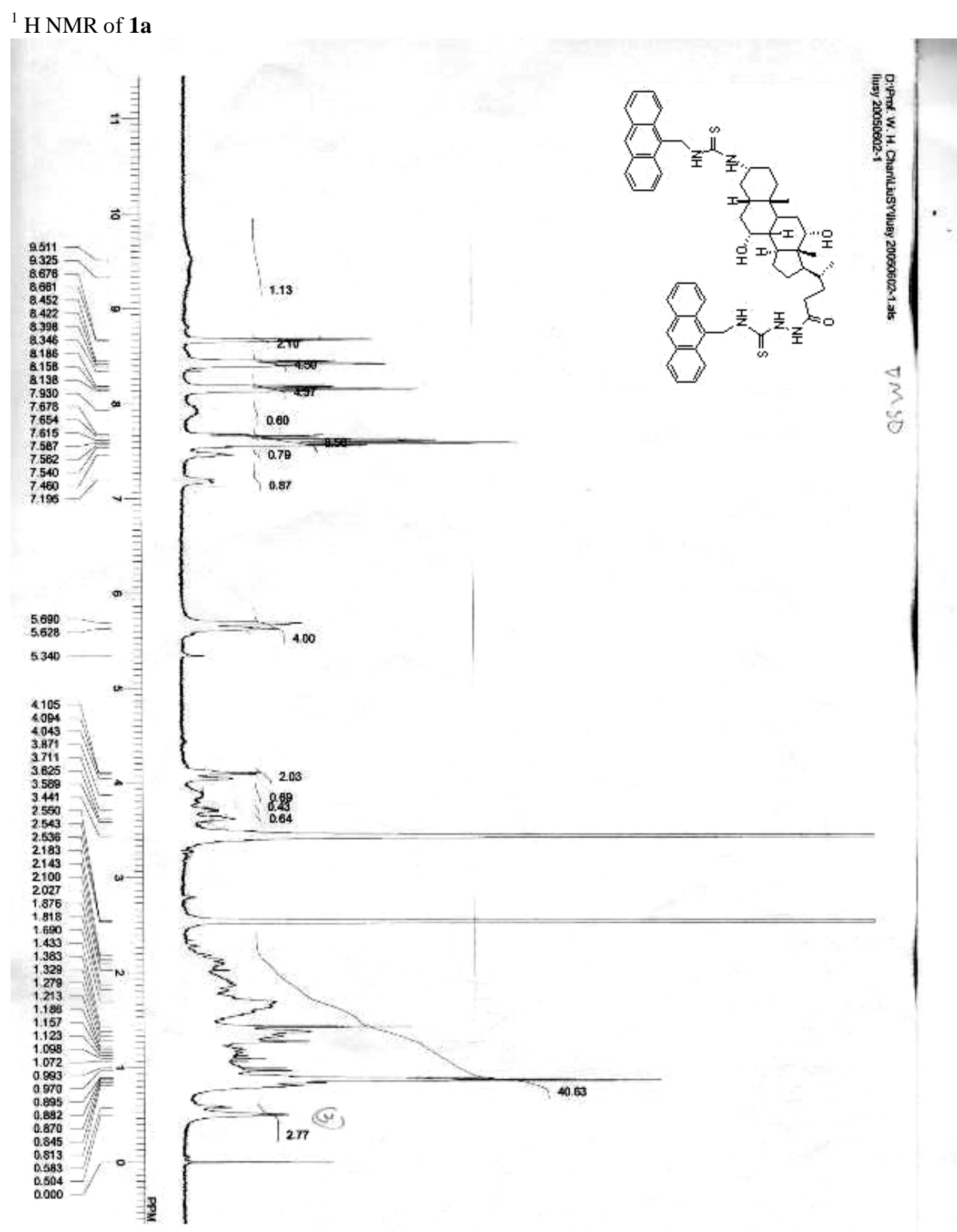

${ }^{13}$ C NMR of $\mathbf{1 a}$ 


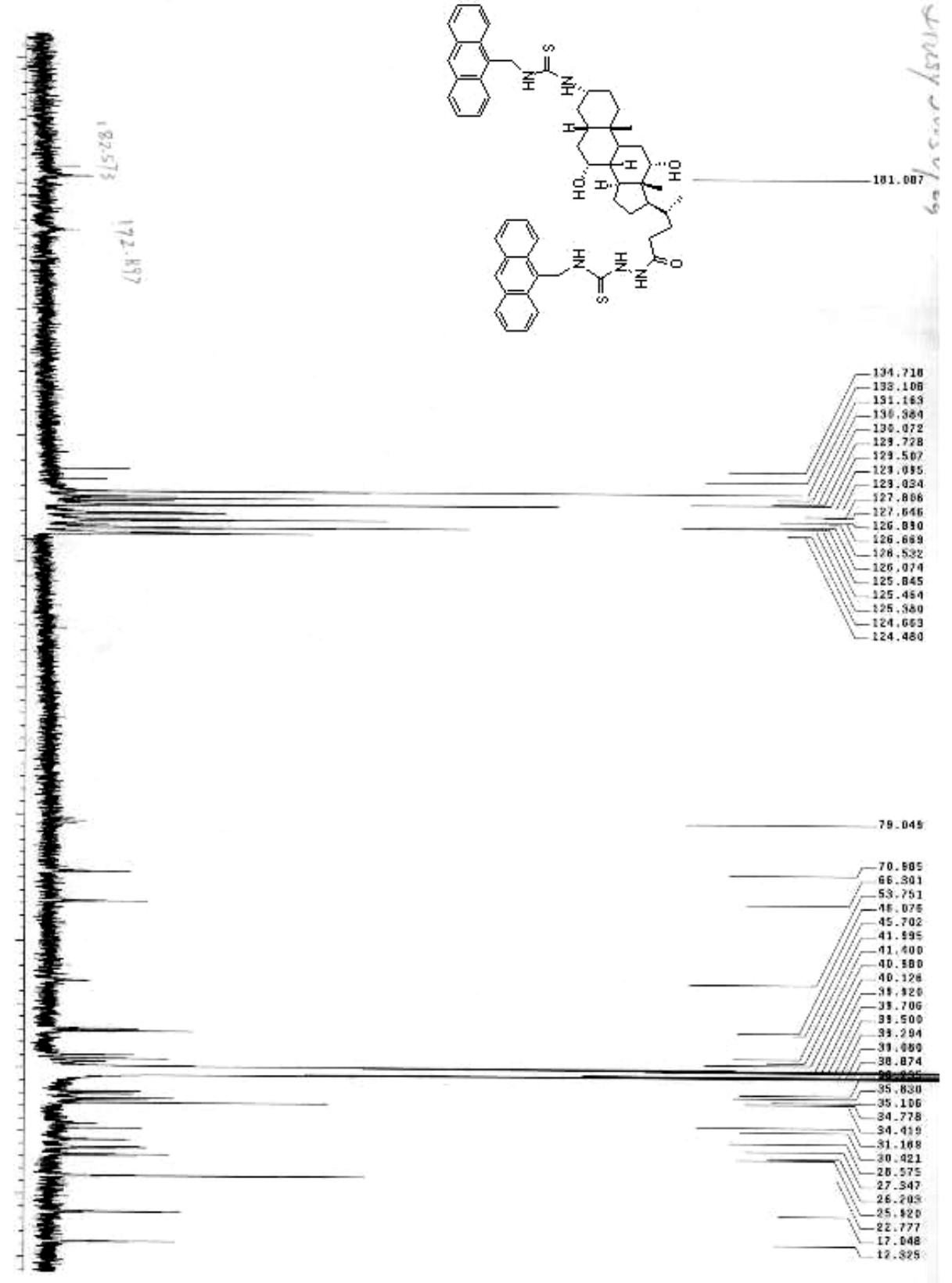

${ }^{1} \mathrm{H}$ NMR of $\mathbf{1 b}$ 


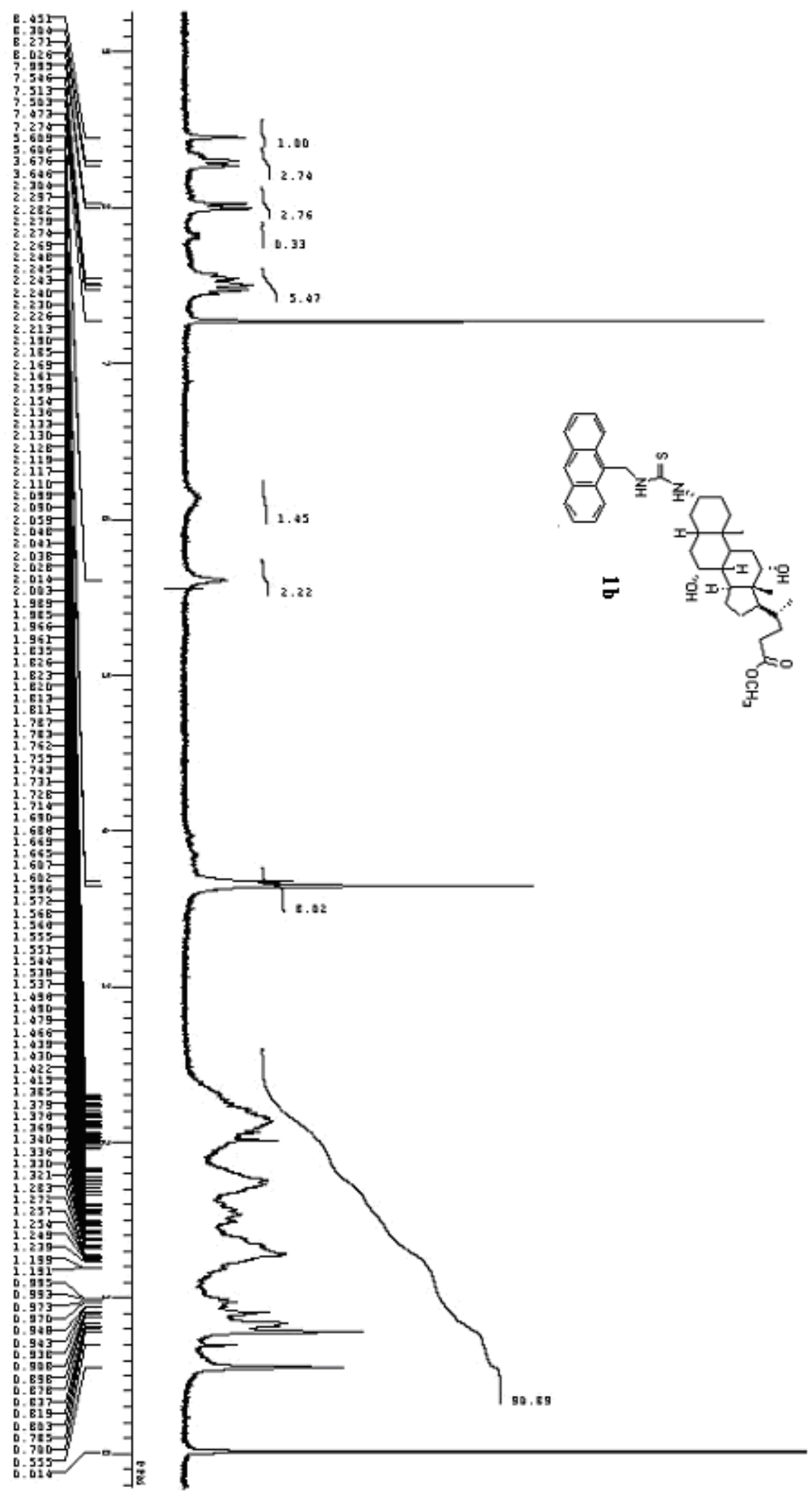

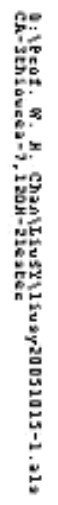

S5 
${ }^{13} \mathrm{C}$ NMR of $\mathbf{1 b}$

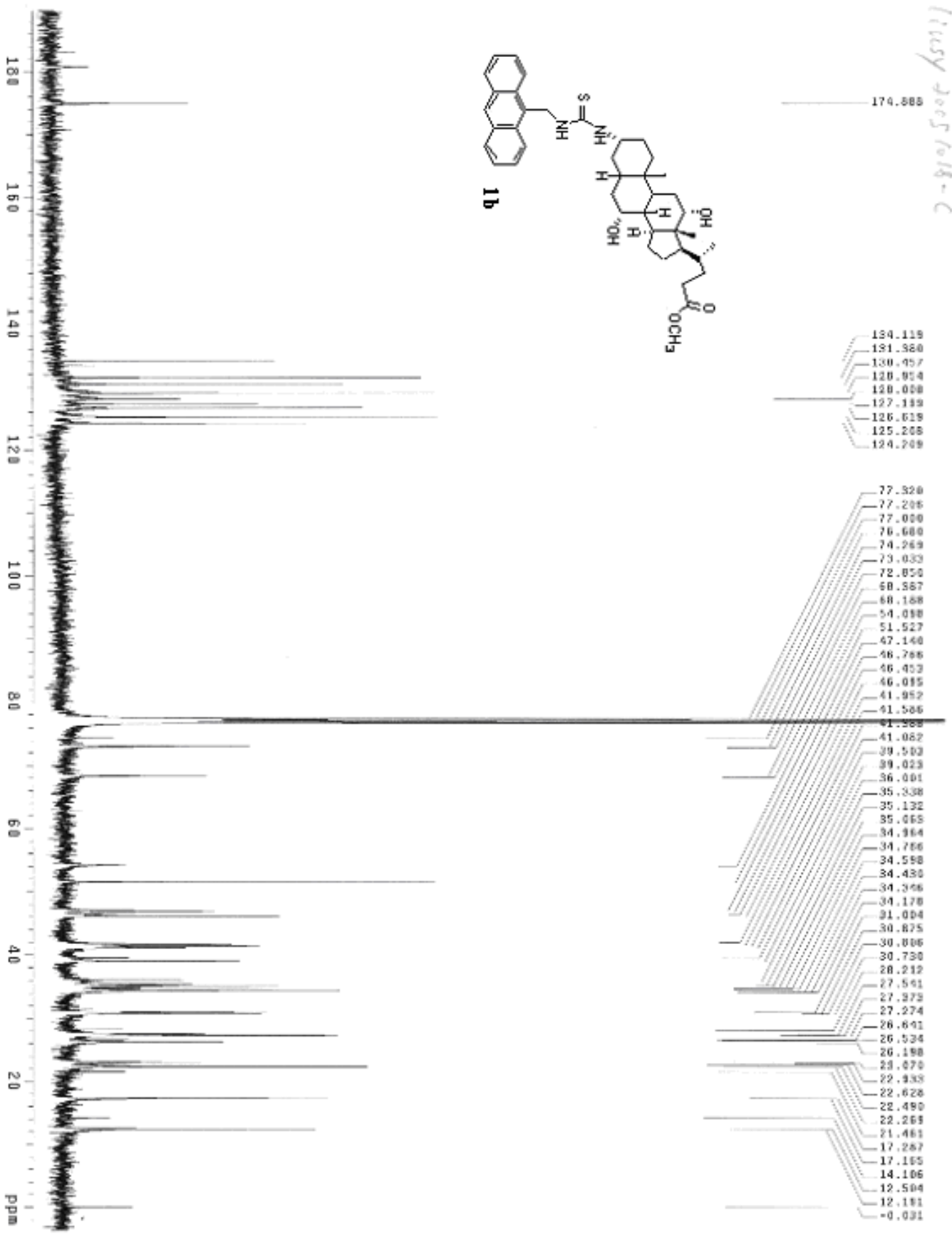

3. Binding experiments 
All dicarboxylate anion were obtained from their dicarboxylate acid treated with 2.0 equiv. of tetrabutylammonium hydroxide in $\mathrm{CH}_{3} \mathrm{OH}$ and dried in vacuum for over night. The structures of these guest anions were verified by ${ }^{1} \mathrm{H}$ NMR.

The studies on the binding properties of $\mathbf{1 a}$ and $\mathbf{1 b}, 1 \mathbf{b}$ and $\mathbf{1 c}$ were carried out in $\mathrm{CH}_{3} \mathrm{OH} / \mathrm{H}_{2} \mathrm{O}$ system $(1: 1,0.01 \mathrm{M}$ HEPES buffer and $\mathrm{pH}=7.4)$. The fluorescence titration were performed with a series of $5.0 \times 10^{-6} \mathrm{M}$ solutions of the receptors containing fifferent amounts of anions.

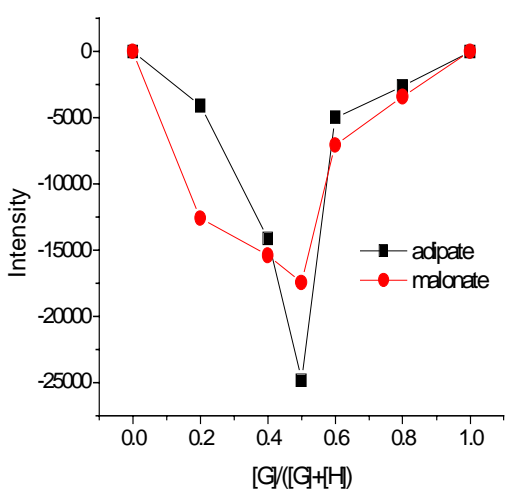

Figure 1. Job plots of receptor 1a (at 413 $\mathrm{nm})$ with malonate and adipate anions.

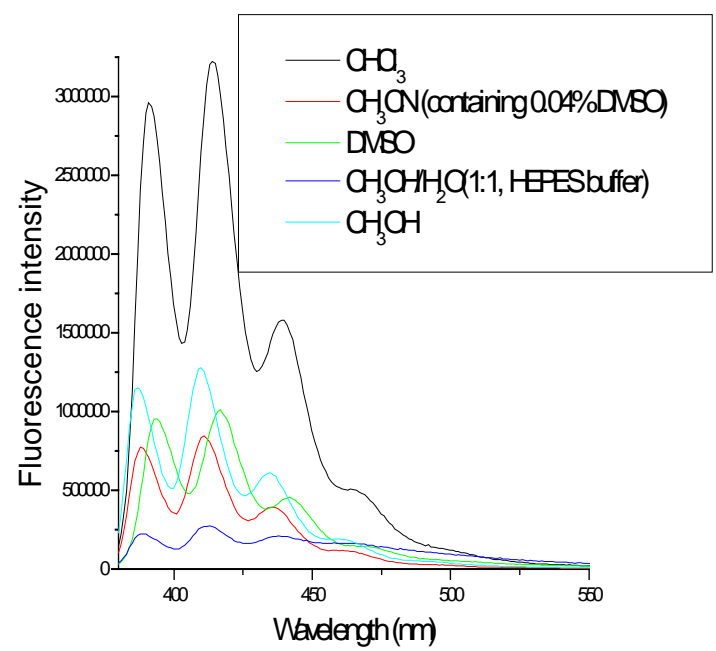

Figure 2. .Fluorescence intensity of receptor $1 \mathbf{a}\left(5.0 \times 10^{-6} \mathrm{M}\right.$, excited at $\left.366 \mathrm{~nm}\right)$ in different solvent system.

4. The emission of $\mathbf{1 b}$ with addition of dicarboxylate anions 

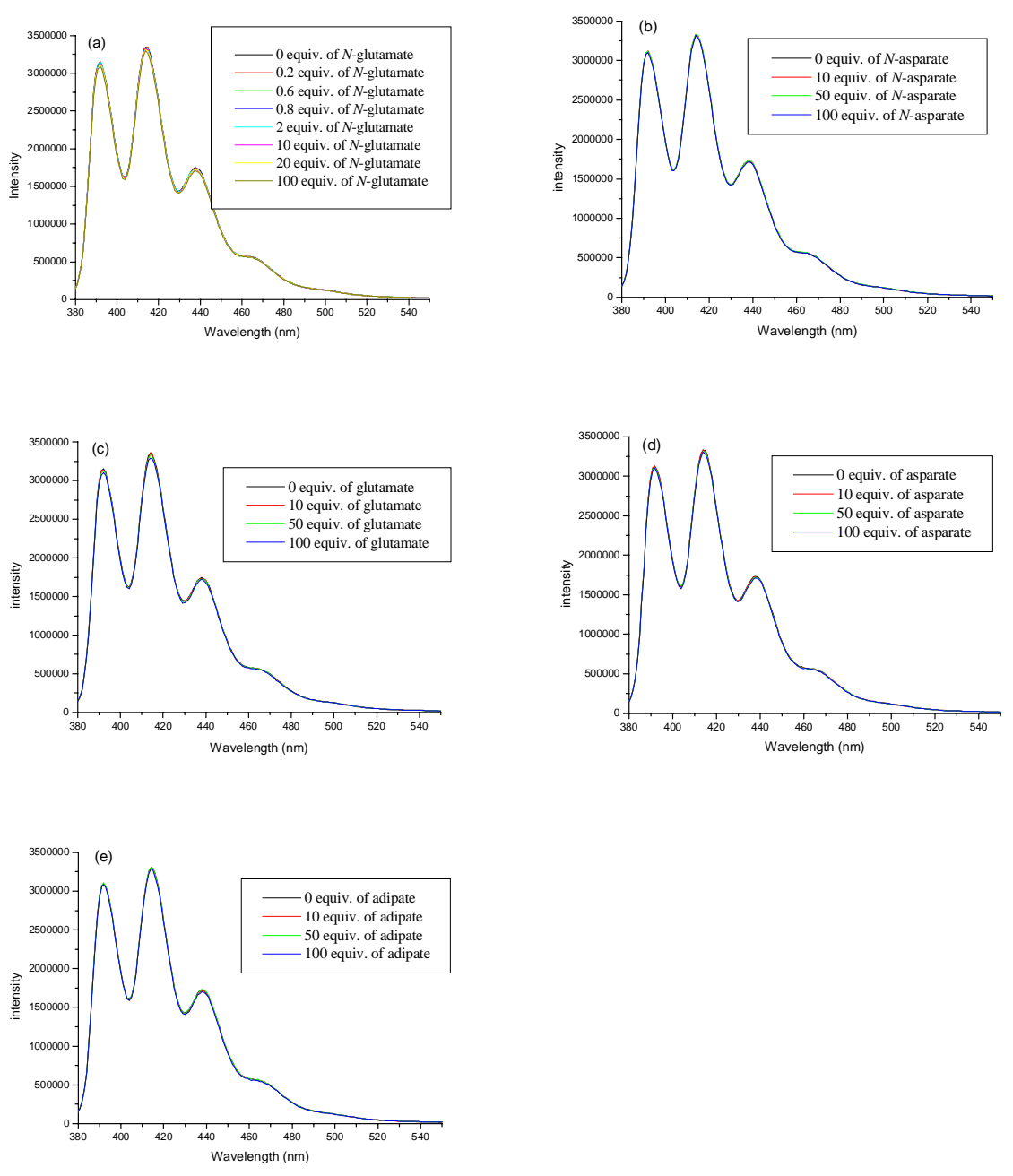

Figure 3a-e: Emission spectra of $\mathbf{1 b}\left(5.0 \times 10^{-6} \mathrm{M}\right)$ with different concentrations of $N$-acetyl-Lglutamate (5), $N$-acetyl-L-aspartate (4), glutamate, asparate, and adipate anions in aqueous solution $\left(\mathrm{CH}_{3} \mathrm{OH} / \mathrm{H}_{2} \mathrm{O}=1: 1,0.01 \mathrm{M}\right.$ HEPES buffer, $\left.\mathrm{pH}=7.4\right)$, respectively $\left(\lambda_{\mathrm{ex}}=365 \mathrm{~nm}\right)$.

5. The emission of 1c with addition of dicarboxylate anions 

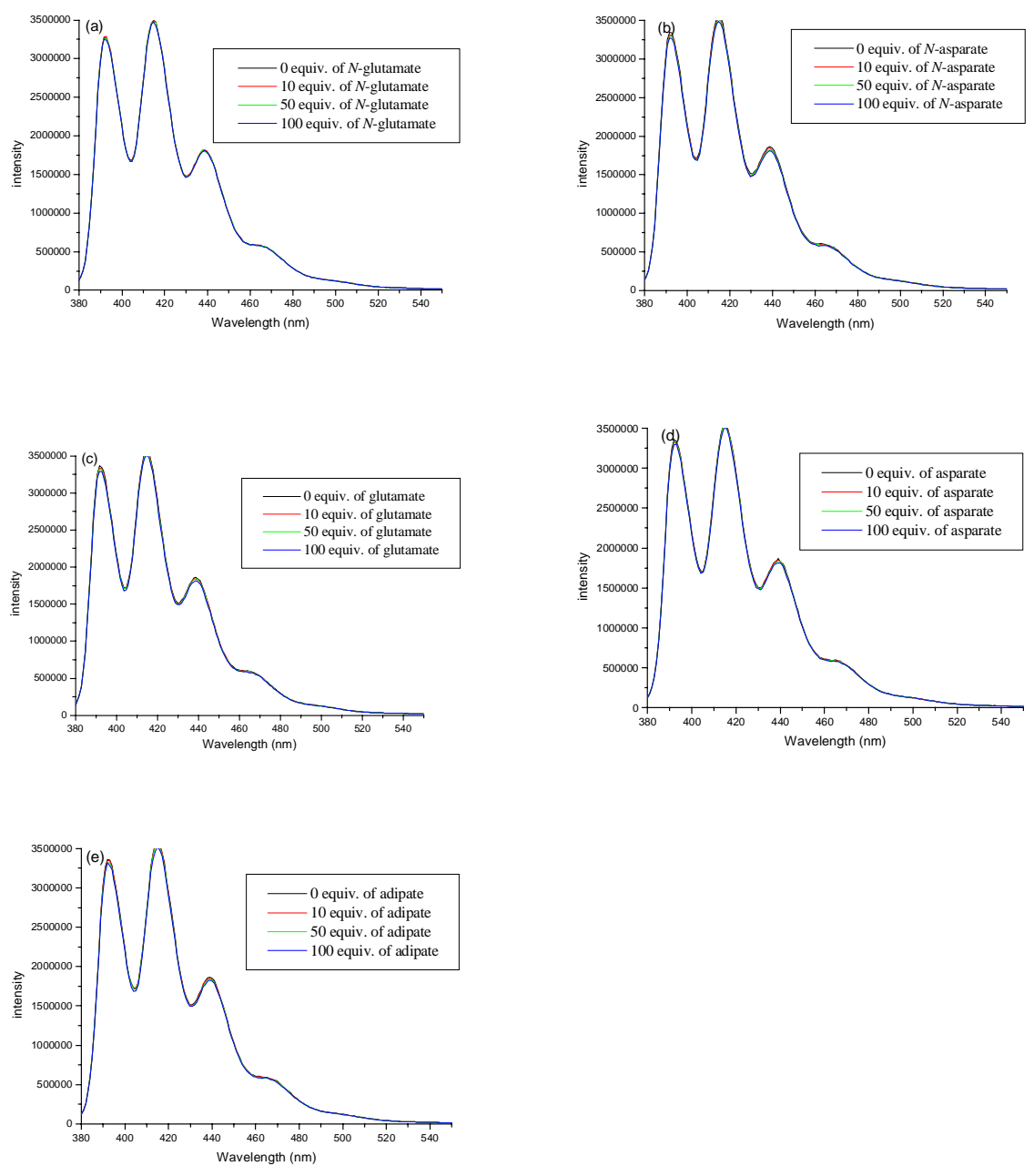

Figure 4a-e: Emission spectra of $1 \mathbf{c}\left(5.0 \times 10^{-6} \mathrm{M}\right)$ with different concentrations of $N$-acetyl-Lglutamate (5), $N$-acetyl-L-aspartate (4), glutamate, asparate, and adipate anions in aqueous solution $\left(\mathrm{CH}_{3} \mathrm{OH} / \mathrm{H}_{2} \mathrm{O}=1: 1,0.01 \mathrm{M}\right.$ HEPES buffer, $\left.\mathrm{pH}=7.4\right)$, respectively $\left(\lambda_{\mathrm{ex}}=366 \mathrm{~nm}\right)$.

6. The ${ }^{1} \mathrm{H}$ NMR of $\mathbf{1 a}$ with $N$-acetyl-glutamate anion 


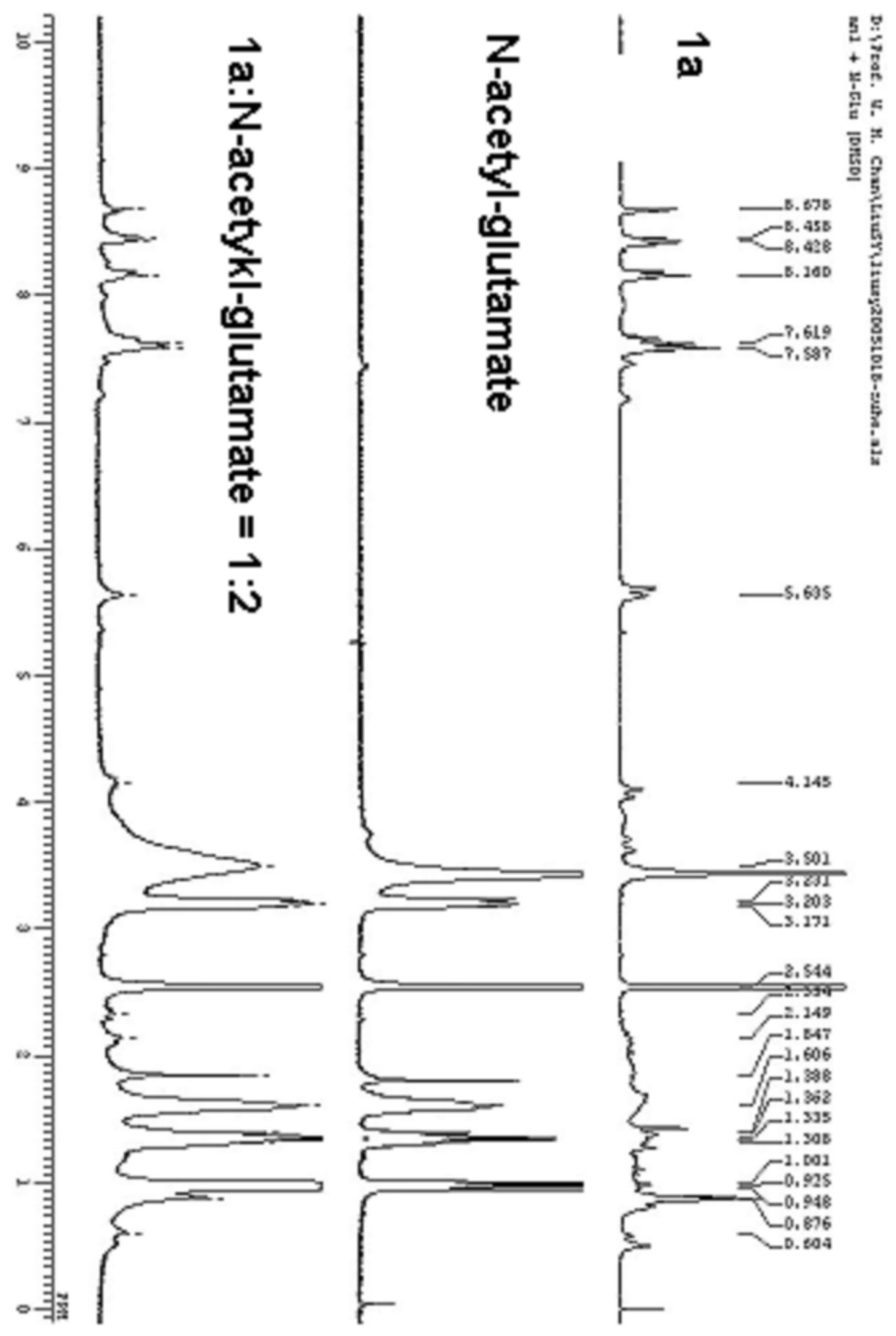

7. Computer modeling data 


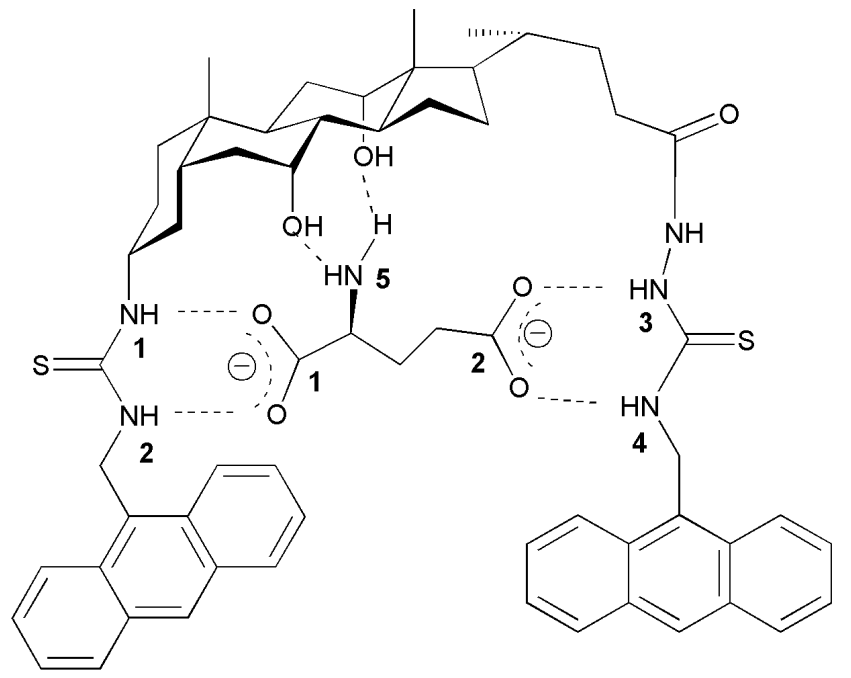

The distance of the C-12 oxygen of the host and the N-5 of glutamate is $3.19 \AA$ which is a moderate $\mathrm{H}$-bond

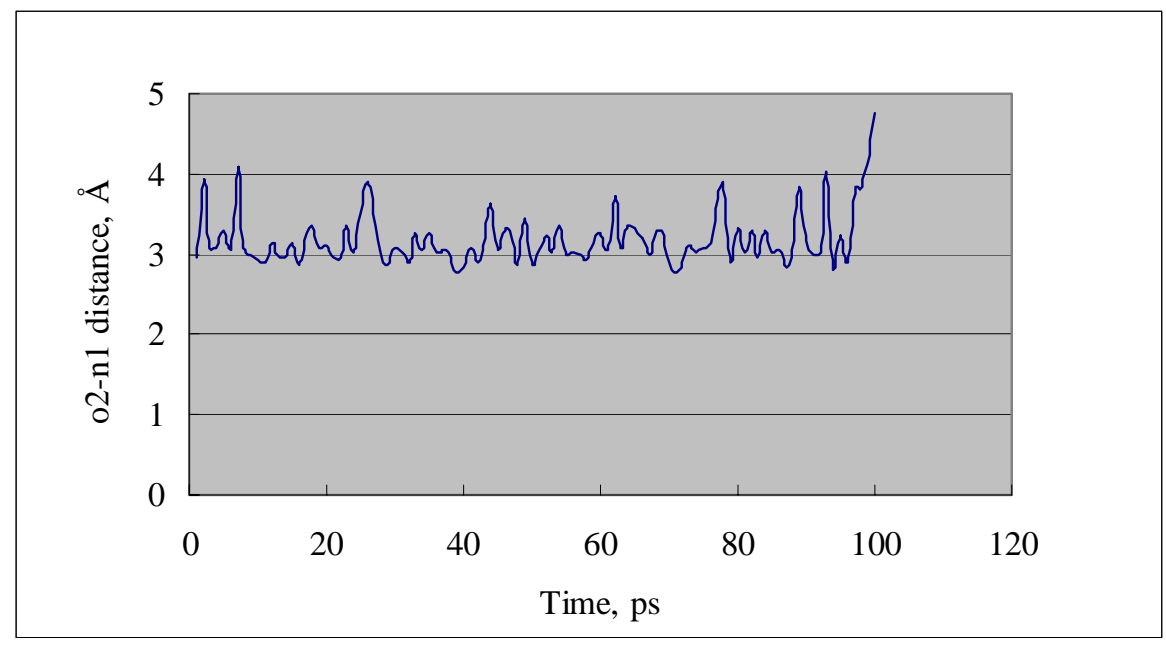

The distance of the C-7 oxygen of the host and the N-5 of glutamate

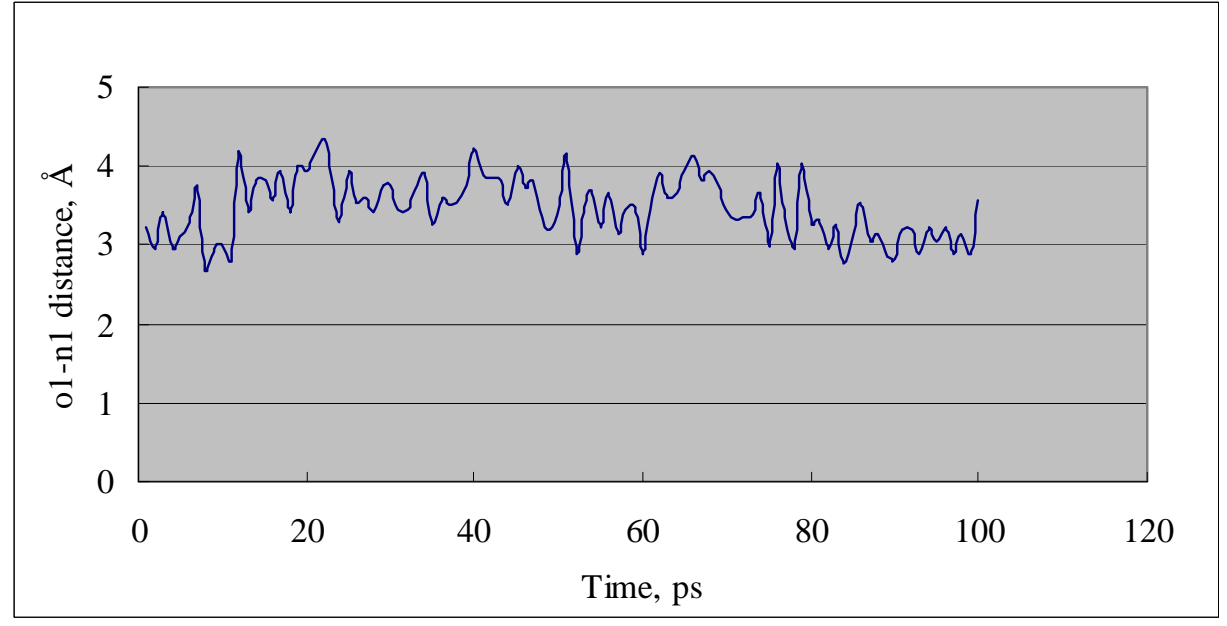


The distance of the N-1 nitrogen of the host and the C-1 of glutamate

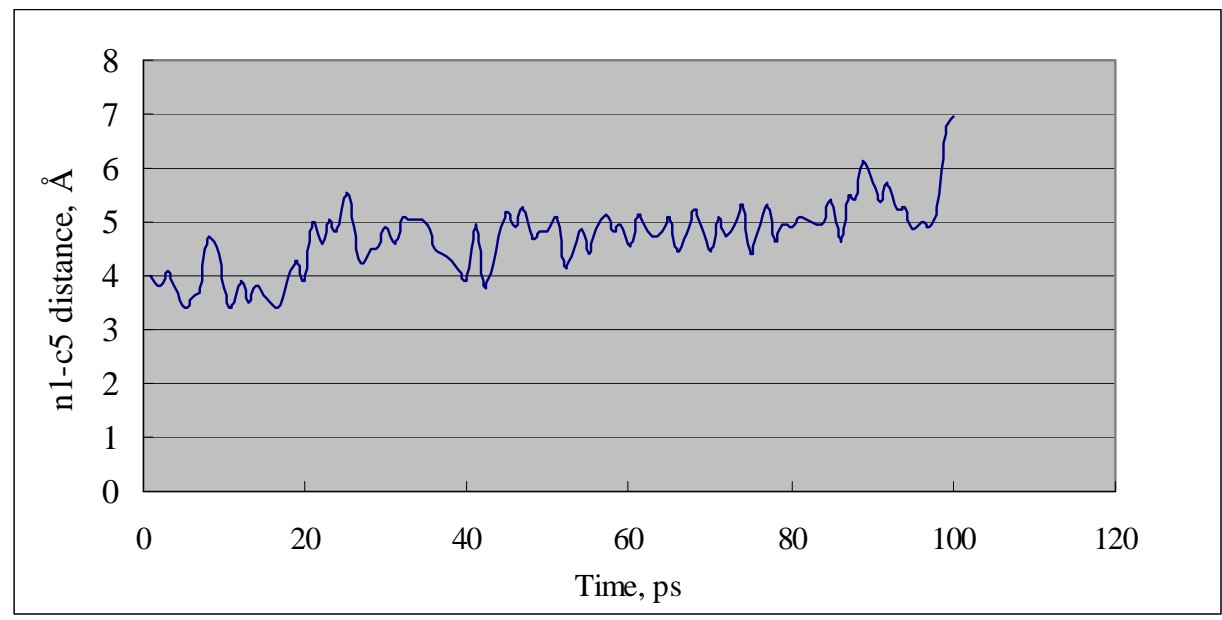

The distance of the $\mathrm{N}-2$ nitrogen of the host and the C-1 of glutamate

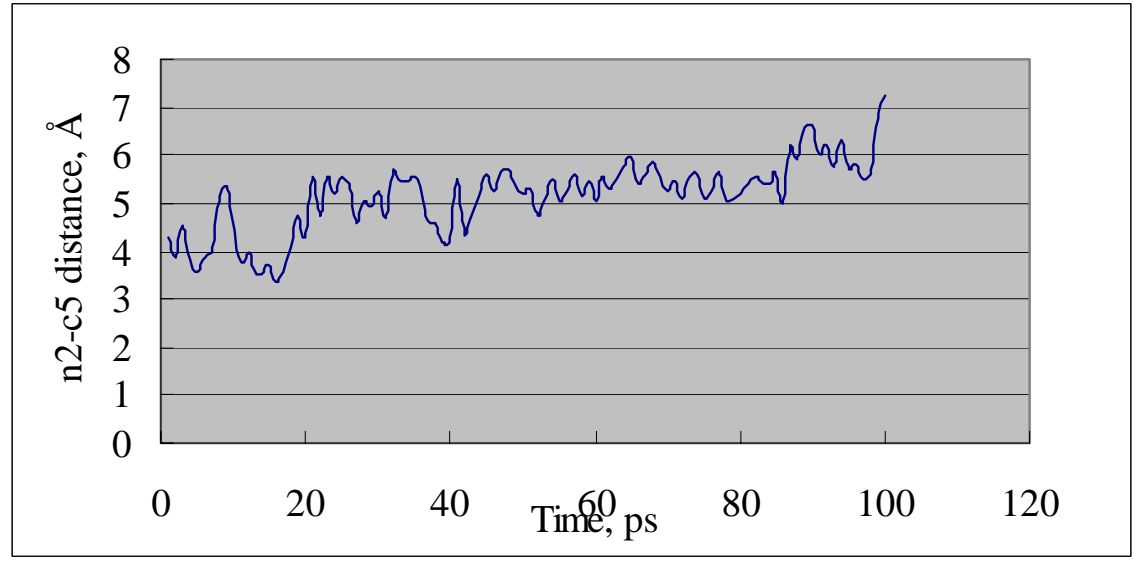

The distance of the N-3 nitrogen of the host and C-5 of glutamate

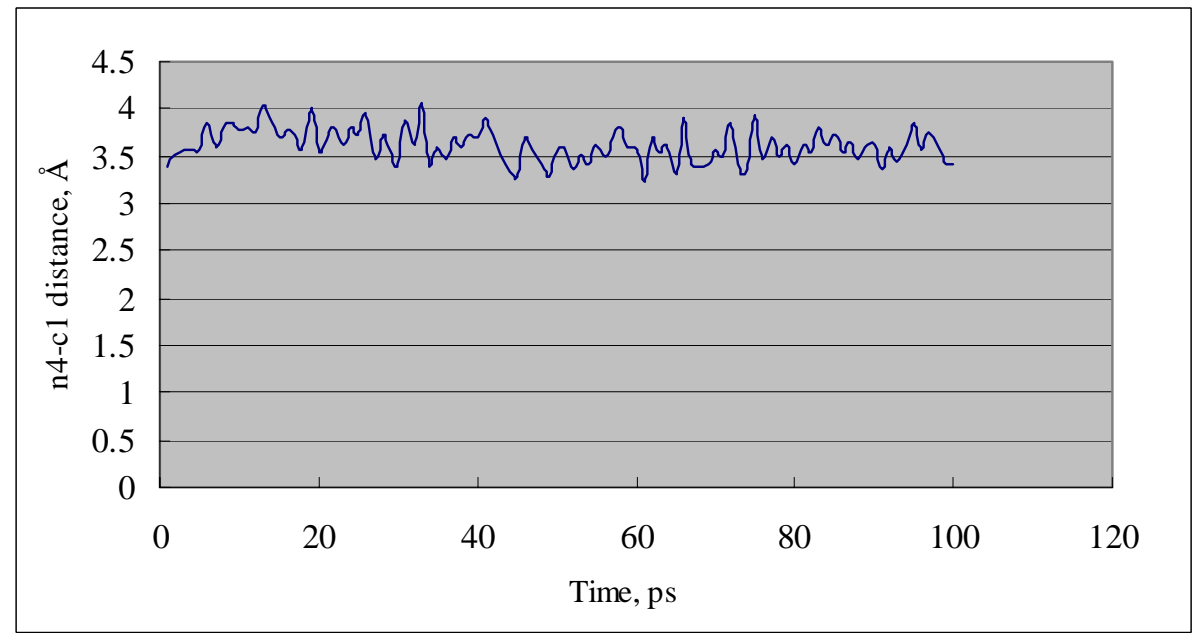

The distance of the N-4 nitrogen of the host and C-5 of glutamate 


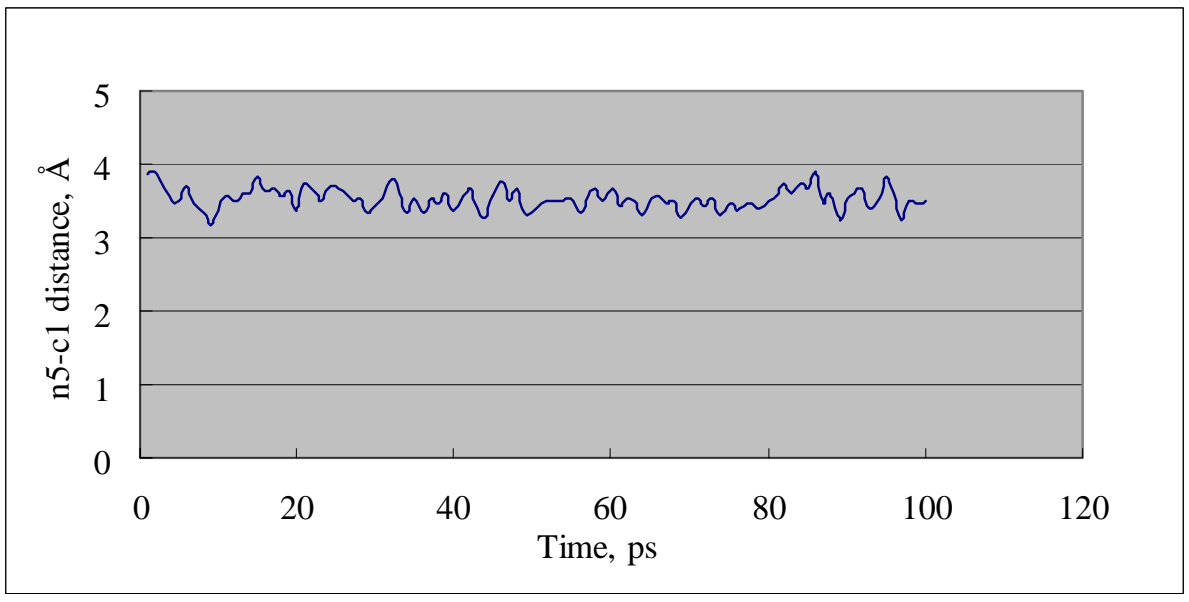

